Hypothesis

\title{
Opportunities for Slow Tourism in Madeira
}

\author{
Josep-Francesc Valls ${ }^{1, *}$, Luís Mota ${ }^{1}$, Sara Cristina Freitas Vieira ${ }^{2}$ and Rossana Santos ${ }^{1}$ \\ 1 School of Technology and Management, University of Madeira, 9000-082 Funchal, Portugal \\ 2 Tourism Project, University of Madeira, 9000-082 Funchal, Portugal \\ * Correspondence: josepf.valls@esade.edu
}

Received: 1 August 2019; Accepted: 12 August 2019; Published: 21 August 2019

\begin{abstract}
The slow tourism movement is gaining popularity as more destinations focus on the local environment and heritage experience. The approach to slow tourism usually occurs either when traditional destinations exhaust their life cycle with an evident reduction in sustainability, or when newly emerging destinations decide to develop in this way. The case of Madeira is different; the island has several decades of tourism development without excessive pressure or overcrowding, and in planning for the future it wants to sustain these conditions. Seeking to understand Madeira's perception of the development model, we surveyed entrepreneurs in Madeira's lodging, restaurant and bar, shopping, transportation, intermediation, and tourist activity industries, as well as its public sector. Even without having encountered the popularized the ideas of slow tourism, Madeira's tourism entrepreneurs show significant alignment with the values of quieter tourism. In contrast to its mature counterparts (i.e., Europe's other popular sun and beach destinations), for Madeira it is not a question of destroying or rehabilitating, but rather of continuing sustainable development processes. Our results suggest that although slow tourism is typically a reaction to a very advanced phase of the life cycle, it can be the result of an endogenous impulse, as is true for Madeira.
\end{abstract}

Keywords: alternative tourism; circular economy; destination life cycle; sustainability; values

\section{Introduction}

Since the inception of mass tourism in the 1960s, in the Mediterranean, the emphasis has been on sun and beach tourism in both island and mainland coastal areas. Based on intensive construction, this model has stimulated mass tourism but has also resulted in depredation of the territory, changes to the environment, the heritage, and the way of life of local residents. It has led to exploitation in the form of tourist monoculture, industrialization of services, mass production and cheap prices, as destinations have advanced through the tourism life cycle phases. Ten years later, the Mediterranean model of massive exploitation of the first square mile along the coast, with high seasonality and standardization, expanded in a very similar fashion in the Caribbean [1-40].

In recent years, slow tourism has been offered as an alternative. It is another way of doing tourism with radically different guidelines: focus on local contact and nearby sights, consumption of local products and heritage, use of clean energy, ecological and ethical vision, and preserving the quality of life of residents and tourists alike. Slow tourism produces more leisurely trips in order to explore the destination more deeply, reduces the carbon footprint, and is committed to achieving a memorable travel experience [1-3].

The slow tourism movement was born in the 2000s, inspired by the slow food movement along with three innovations in the tourism sector: First, the coastal sustainability effort [4]; second, advances in the quality of services and the implementation of the SERVQUAL model in the hospitality industry [5]; and third, a new emphasis on emotions and values as key factors for travelers as they choose among multiple destinations [6]. 
In the midst of this scenario, some island destinations such as Madeira have avoided the ill effects of mass tourism. Although located in a climatic-geographical zone suitable for the mainstream tourism model of sun and beach, as promulgated in the Mediterranean and the Caribbean, Madeira has preserved its territory and local culture, opting for a set of values considered close to those of slow tourism. Yet Madeira has been unable to develop its own relationship models with tourists.

The objective of this paper is to explore whether Madeira's vision of tourism and its entrepreneurs' practices are aligned with slow tourism, whether or not they call it by this name.

\section{The State of the Question of Slow Tourism}

Slow tourism is gaining popularity in both advertising in general and in the strategic planning literature of destinations. In many cases, in that context, it seems more an easy label to use than a clear, defined, and scientifically consistent term. On the island of Madeira, there appear elements of slow tourism, impulses, or particular perceptions that many of their products or the island itself can considered as such, although the label itself is rarely used. We intend to show that indeed the characteristics of Madeira's tourism development fit with the basics of slow tourism, and that although the island's tourism entrepreneurs are not openly favorable, they are willing to assume this development model (the three proposed hypotheses). Hence, we present a thorough review of the scientific literature around the following three concepts. The first of these is related to the radical change of the tourism model, which in turn is broken down into: Improvement of the sustainable and natural environment; change in the concept of travel and the use of time during one's trip; alternatives to mass tourism, local and cultural; and promotion of an improved quality of experience thanks to the authenticity it offers. The second is related to feasibility and new business development, since it raises business models little explored heretofore. The third is related to the specific characteristics of the island of Madeira, where we have studied the phenomenon.

\subsection{The Origin of Slow Tourism}

Slow tourism developed during the 2000s, inspired by the slow food movement-a reaction against standard food products, fast food and foods of unknown origin, in favor of local products, healthy eating, and foods of recognized traceability. The slow food movement was founded in 1989 as a protest against the proliferation of the fast food industry invading Europe [7]. Slow food, while not anti-consumption or anti-capitalism, is predicated on ethical approaches to production and consumption; the terms "eco-gastronomy" and "virtuous globalization" are sometimes applied to it [8]. A challenge for the European food, diet and food industry is to orient consumption toward foods that are sustainably produced. Ethical consumer movements like slow food appeal to a consumer's virtue. Such approaches ask consumers to reflect on what type of person they would like to be and provide guidance in how to self-actualize and self-fulfill. By using culinary tourism to convey the pleasure of consuming food differently, the slow food movement appeals to consumers' private virtues and attempts to coalesce these into public virtues [9].

Slow food and its principles have inspired a number of other subsequent movements [10]. One salient offshoot is the advocacy of slow travel as an alternative to mass tourism's fast-paced, escapist vacation. Embracing similar sentiments to slow food's culinary focus, it concentrates on the enjoyment of the journey rather than just physical travel as a mode of transport to a destination [11].

The first factor contributes to balancing the environmental conditions that had deteriorated significantly in the preceding two or three decades. The pressures of the mainstream mass tourism model during the 1960s through 1980s resulted in damage to Europe's islands and coastal areas that is evident in the regions' environmental aspects, including infrastructure, services, water shortages, inadequate waste treatment and disposal, and erosion of beaches, as well as the historic centers of the coastal municipalities [1,12-15].

The movement against the unsustainability of the mass tourism model began in the 1990s in the Mediterranean; a few years later numerous destinations on the Caribbean coast began to adopt the same 
practices. The uncontrolled growth of the number of tourists and the real estate occupation model of the territory were approaching an environmental point of no return in several coastal destinations. Under public pressure, a series of revisions of the mainstream model were initiated in order to reduce the tourist impact on the most fragile areas of the coast. The cases of sustainable Calvià [16] and Lanzarote Biodiversity [17] are paradigmatic of that revision process of the mainstream model. Its main objective was to curb the runaway growth of coastal destinations to make territory and heritage sustainable.

The second factor that drives slow tourism relates to the great advances made around quality of services and the SERVQUAL model. The demands of customer satisfaction increase as travelers become more familiar with tourism; such demands are detailed in precise aspects of quality in the services to which the people in contact and touchpoints of tourism companies must respond [4,5,18-24]. The disadvantage of quality improvements is that they increase production costs, and therefore the final prices to consumers. Nevertheless, the low-cost economy has made great progress in reducing costs.

Moreover, the third factor, the focus on travel experience, is added to slow tourism because of the first two. It connects with them by bridging the gaps leading to the quality of service and improves the customer experience in the digital age [25-33].

\subsection{Attributes and Definition of Slow Tourism}

Slow tourism adopts elements of this trigger and of the three factors, as well as incorporating others of its own, resulting in the configuration of a new concept of tourism. To define it, we have broken down the most outstanding bibliographical contributions according to the different attributes (Table 1).

Table 1. Slow tourism attributes authorship.

\begin{tabular}{cc}
\hline Attributes & Authors \\
\hline Change in the concept of travel and the use of time & {$[1,3,7,8,14,35,36,38,39,41,42]$} \\
during the trip & {$[4,6,7,40,43-45]$} \\
Alternative of mass Tourism & {$[1,2,15,35,36,46-50]$} \\
Local & {$[15,35,37,51]$} \\
Cultural & {$[2,6,8,9,16,34,39,46,52-54]$} \\
Sustainable and natural environment & {$[11,12,29,34,35,55]$} \\
Change in the quality of the experience & {$[1,2,15,36,56]$} \\
Authenticity & {$[35,57]$} \\
Feasibility and new business development &
\end{tabular}

The new concept proposes a radical change to the use of territory, recognition of heritage and the relationship with the destination: A slower experience over land, staying longer and traveling less [34]. With this change, the high environmental cost of the mainstream model—speedy transit by car and airline, intensive resources, maximizing visits, services standardization-passes to a less aggressive one characterized by slower travel timing, localness, low carbon footprint, customization, slow food and beverage choices, and resource reduction [1]. The slow tourism movement is a niche interest in tourism. Just look at the list of topics that relate to it though: Adventure, agritourism, cruises, ecotourism, education, indigenous observation, medicine, music, religion, and volunteering [40]; and we could add, referring to Madeira, sport tourism, trekking, running, birdwatching, and more. These are historical tourism motivations that acquire great relevance in the light of slow tourism. It stands as an antithesis to fast tourism [14] and is a form of political consumption and a new form of sustainable tourism development that is based on the push-back against modern society's fast lifestyle, ideology, and consumption practices [17]. The change of vision affects not only the way of looking at things relating to the territory, heritage, and people, but also to the use of alternative transport [35]. 


\subsubsection{A Change in the Concept of Travel and the Use of Time during the Trip}

As opposed to mass tourism, slow tourism emphasizes: Regionality, authenticity, uniqueness, sensations, creating one's own journey, vacation rentals, commitment to local culture and history, quiet, treating the tourist as a temporary resident, joining in as much as possible, staying awhile, de-commoditization, slow food and beverage choices, and discovery $[1,38]$. There are three identifiable behavioral categories of what can be termed slow tourism. First, there are studies that focus on modes of transport that have reduced environmental impact and less travel (alternatives to air and car travel). The second emphasizes better tourism experiences, where visitors engage in a deeper experience of the place. The third focuses on transport as a tourist experience [38]. Others have argued that slow tourism is better seen attitudinally rather than as a category of behavior [39]. Fullagar, Markwell, and Wilson [14] pointed out the existence of a tension not easily resolved within slow philosophies regarding the carbon footprint created by air or car travel.

According to Molz [40], whether fast is seen as a valuable attribute of the productive citizen or slow is seen as a more centered or sustainable mode of travel has less to do with speed itself, and more to do with the way experiences and representations of pace are shaped by race, class, gender, and nationality. The author concluded that what people "travel for" is not necessarily to arrive at a destination, but to be on the road and in the world in a particular way. What matters is not how fast or how slow, but how we orient ourselves within the complex temporal landscapes of travel, and how we harness pace as a way of making sense of ourselves, of our travel companions, and of the world. In this context, slow tourists may choose a physically slower mode of transport to facilitate the necessary deceleration-or, alternatively, may take solace in a flight that detaches them from the stresses and strains of daily life and instead offers an opportunity to become reconnected with their thoughts [52].

\subsubsection{An alternative to Mass Tourism, Local, Cultural}

As an alternative to the mass tourism that has developed in coastal areas, slow tourism-not only on the coast but also in inland rural and urban areas-reinforces the local and the autochthonous culture; exchange with residents, with their roots, with their language and their customs and lifestyle. The concept of holidays changes in the slow tourism model. The tourist in contact with the territory, the landscape, and the people of the local destination [19] find, these to be the main benefits of the trip. One can also add the dimensions of events, local festivals, and the arts. Slow tourism modifies the vision of the territory and heritage, and therefore its use. In this way, it opens a new perspective for the trip and enriches alternative tourism.

The tourist's journey mixes with the local community, producing important effects of multiculturalism, including zero-kilometer products, traditional cuisine, local trails, archaeology, traditions, tranquility and calm coexistence. These attributes not only improve the customer experience but also benefit the business services and contribute to the agricultural and industrial success of the local community.

Faced with a model based on the continued growth of the number of tourists and real estate, slow tourism proposes an endogenous management of resources [8]. The management of resources must develop within a plan according to the carrying capacity, seeking ecological integrity and territorial balance. Therefore, it is offered as a solution to numerous problems generated by the traditional model of monoculture tourism, which has reduced the role of the rest of the agricultural, service, and industrial sectors; resulted in overcrowding; devalued resources; gentrification; brought about confrontations between tourists and residents, and between communities; and modified native ways of life.

For the cultural exchange between residents and tourists to produce common benefits, it must be based on two commitments. First, a commitment by visitors to honor the local culture and appreciate its values, attitudes, and beliefs. Secondly, by the recipient destination to provide valued resources, quality services, and hospitality. Far from confrontation, the result must produce multiculturalism and adaptation, which translates into satisfactory experiences for tourists and acceptable costs 
for residents [58]. Furthermore, slow tourism as a sociocultural phenomenon develops a strong environmental awareness that leads travelers to seek local experiences using much more green transportation than other tourists [16].

\subsubsection{Improve the Sustainable and Natural Environment}

The relationship between the traveler and the destination acquires an ethical dimension [43], since it is no longer a question of the former using territory and heritage for their holiday enjoyment, but to produce a beneficial exchange for both of them. Because of the revitalization and self-enrichment sought, the environment not only does not deteriorate; it actually improves. Sustainability refers not just to the environmental factor, but also to the economy, the sociocultural, the human factor, the sense of hospitality, the sense of belonging to a place, the kitchen, and so forth [42].

International organizations such as UNEP, 2011 and UNWTO, 2000, suggest that there is still a misconception that only ecotourism can be considered sustainable tourism, when in fact all forms of tourism should move toward becoming more sustainable by focusing on the three pillars of sustainability: Economic, environmental and sociocultural. In this respect, much of the early focus on slow tourism has generally supported the concept with strong environmental arguments, defending slowness as a valuable opportunity to reduce tourism's high pollution and carbon footprint. Instead, the tourism industry has mainly focused on the experiential and regenerative power of the slow tourism experience and the dimensions of motivations [43].

This process requires that all planning be fundamentally based on the area's carrying capacity, which limits both the size and intensity, and affects the technical capacities, dimensions and indicators to control the pressure on its physical-ecological, sociodemographic, and political-economic aspects [50].

\subsubsection{Promoting Changes in the Quality of the Experience as It Offers Authenticity}

Authenticity is the antithesis of commoditization [2]. The traditional approach to travel experiences through mass tourism is unavoidably insufficient to fulfill the new expectations of tourism activities and to ensure the overall satisfaction of tourists [51]. The growth of alternative forms of tourism confirms the importance of the dimension of consciousness, as knowledge of self and others, and as awareness of the impact that one's presence has on the environment. In other words, the new tourism is a response to problems that have arisen from the previously predominant mass tourism, including environmental, social and cultural disasters; unequal distribution of financial benefits; the promotion of paternalistic attitudes; and even the spread of disease [47].

The experience based on authenticity connects with the desire to know the world in a different way [14]. It has been argued that authenticity is valued only when its absence is perceived [54].

\subsubsection{Feasibility and New Business Development}

A critical question must be asked: Is slow tourism economically viable? [56]. In order for a tourist destination to be profitable, it is necessary to have enough tourists, which translates into the existence of a segment or niche of customers who want to visit that destination. Secondly, new businesses may arise, and thirdly, tourists need to make appropriate purchases. In addition, businesses must obtain good margins [38]:

- In any case, numbers of flow-movement members, the variety and the rapid international growth of slow tourism, predict important opportunities for tourism suppliers seeking a position in this market.

- While slow tourism has inspired new ways of doing business, it is difficult to quantify its economic impact, since it is an emerging market. In the capacity to create new businesses, and therefore wealth and jobs for slow tourism destinations, we will distinguish six sections:

Thanks to slow tourism, new businesses are generated, such as artisan and zero-kilometer markets; museum spaces; informative, meeting, and exchanging places; the transformation 
of local products; the expansion of visits to places less known by the general public; and the recovery of the local social culture.

0 New services of accommodation, restaurants and catering services, guidance, interpretation, and transportation and marketing.

0 The development of environmental policies around the landscape, heritage, green transport, recycling, and the circular economy

- The seasonally adjusted tourist seasons, insofar as this type of tourism is not so conditioned by the weather or the standard seasons.

- Entrepreneurship that embraces creativity.

○ General technological development; Caffyn [37] says that slow tourism is absolutely compatible with new technologies; he even insists they are needed.

- A more personalized, quieter trip invites one to spend more, due to the value of experience. Consumers' actively choosing smaller providers assumes their ability to afford the often-higher prices that local retailers may charge for goods/services, due to their lack of economy of scale. If we are what we eat, then the same could be said of our travel choices [5]. In addition, as materialistic values are reduced and emotions and affects increase, availability of spending increases $[57,59]$. This would imply that a better service, removed from overcrowding, would facilitate a better profitability of the establishments.

- The result of the previous points would mean that business profit could support the new model.

\subsection{Slow Tourism in Madeira}

Madeira is an ultra-peripheral autonomous region in Europe, located in the North Atlantic, within the same temperate geo-climatic zone as the Mediterranean and the Caribbean (Figure 1); it is of volcanic origin like the rest of the islands in Macaronesia. Madeira itself is a set of islands of which only two are inhabited: Madeira, where $90 \%$ of the archipelago's population is concentrated, and Porto Santo Island. Madeira Island's surface is $741 \mathrm{~km}^{2}$; it is $57 \mathrm{~km}$ long and $22 \mathrm{~km}$ wide. These dimensions place it among the medium-sized islands of Europe. It has a resident population of slightly more than 250,000 , and in 2017, 1.2 million tourists arrived on the island, 5.2\% more than the previous year; the hotel capacity is 29,000 beds [60].



Figure 1. Madeira, in the same geo-climatic region as the Mediterranean and Caribbean seas. Source: Adapted from Google Maps and www.ngdc.noaa.gov. 
Madeira's tourism feeds mainly from the European markets, mainly the United Kingdom, Germany, Portugal, France, and Spain. The annual hotel occupancy rate is $64.6 \%$, exceeding $60 \%$ of the occupancy in the eight-month period from March to October [61]. This ratio places it as one of the most de-seasonalized islands in Europe.

In the last five years, Madeira has grown moderately $(22 \%)$ in its number of tourists, a growth rate below that of the large islands in the Atlantic (Canary Islands) and the Mediterranean (Balearic Islands, Corsica, Sicily, Malta, Cyprus), for a period in which all have become an alternative destination for those fleeing the Arab spring and terrorist crises in other Mediterranean countries. Madeira has not seen a significant increase in tourist real estate construction, prioritizing instead the improvement of the occupancy of existing establishments. This restrictive criterion, which requires strict environmental management of all projects, energy efficiency, and waste management, is based on a tourism development model that clearly differentiates it from the traditional sun and beach: The destination is identified with a growth focused more on quality than quantity, and is associated with values such as authenticity, culture, innovation, and creativity [62].

The parallel between the attributes that are self-proclaimed by Madeira and the components of slow tourism that this paper analyzes is striking. Madeira's attributes include its exuberant nature (heritage of humanity), mild climate throughout the year, superior quality of service, tourist tradition (genuine hospitality), history and culture, variety of sea and mountain activities, proximity and accessibility to markets, and safety [62].

\section{Objectives, Hypotheses, and Methodologies}

Madeira is in the same geo-climatic zone as the Mediterranean and the Caribbean, where a massive tourism model has been developed around sun and beach vacations. However, Madeira has not followed this model, instead opting for a set of values that appear to coincide with slow tourism. The objective of this study is to discover the extent to which the vision of Madeira's tourism entrepreneurs is in line with slow tourism, whether or not they call it by this name. In this regard, it is to confirm whether they hold a favorable attitude toward reinforcing slow tourism criteria and applying them on the island.

To achieve these objectives, the hypotheses are:

H1: The characteristics of Madeiran tourism development fit in with the basics of slow tourism.

H2: There is no openly favorable attitude toward slow tourism among tourism entrepreneurs in Madeira.

H3: Tourism providers on the island would be willing to carry out this model of tourism and apply it.

In order to validate these hypotheses, the following methodology is proposed:

- To demonstrate H1: (a) Analysis of strategic plans and compliance with results: Evolution of the compared overnight stays; (b) Madeira benchmarking with the Canary Islands, Mallorca, Sicily, Corsica, Malta, Cyprus, Cabo Verde, and Azores: Global number of tourists, global number of rooms, ratio of tourists per square kilometer, ratio of occupancy versus seasonality, and number of tourists versus residents.

- To demonstrate $\mathrm{H} 2$ and H3, a questionnaire was written to obtain the perception about the topic, being sent to a representative sample of hotels, restaurants, shopping centers, transportation companies, travel agencies and online travel booking sites, and tourist attractions.

To validate the hypotheses, a 19-item questionnaire was written, focusing on the tourism model of each establishment, its capacity for innovation, and its classification. Once the questions were drafted, two initial group tests were carried out: The first with professors from Ramon Llull University's Tourism Project and the second with tourism business managers. The questionnaire was reviewed and re-tested in a selective and short sample (10 cases). From June to September 2018, six surveyors of the university went randomly to the headquarters of the various establishments, by appointment. 
In Madeira's study area, there are 924 registered tourism related business, and the sample obtained consists of 182 surveys administered to the managers or owners of these establishments, representing $17.53 \%$ of the total (Figure 2). Nevertheless, fieldwork has $6.51 \%$ error from the original error calculated, and the sampling error was considered suitable for the study. The distribution by sectors is the following:

- Accommodation: 124 establishments, of which 33 were surveyed (26.61\%). The Accommodation heading includes hotels of all categories, quintas, residential accommodations, and hostels.

- Food and Beverage: 167 establishments, of which 43 were surveyed (25.75\%). Within Food and Beverage, restaurants and bars were included.

- Shopping: 106 establishments, of which 29 were surveyed (27.36\%). Within Shopping, we included stores selling all kinds of products from souvenirs to clothing and consumer goods.

- Transportation: 74 establishments, of which 10 were surveyed (13.51\%). Within Transportation, we included bus companies, rental car companies, bicycles, public transport, ferry, and cruise.

- Intermediation: 346 establishments, of which 18 were surveyed (5.20\%). Within Intermediation, travel agencies are included.

- Tourism Activities: 78 establishments, of which 21 were surveyed (26.92\%). Within Tourism Activities, we include outdoor activities, tours, walks to levadas, and caravel tours.

- Public Sector: 29 establishments, of which eight were surveyed (27.59\%). Within Public Sector, autonomous government, municipalities and public corporations are included.

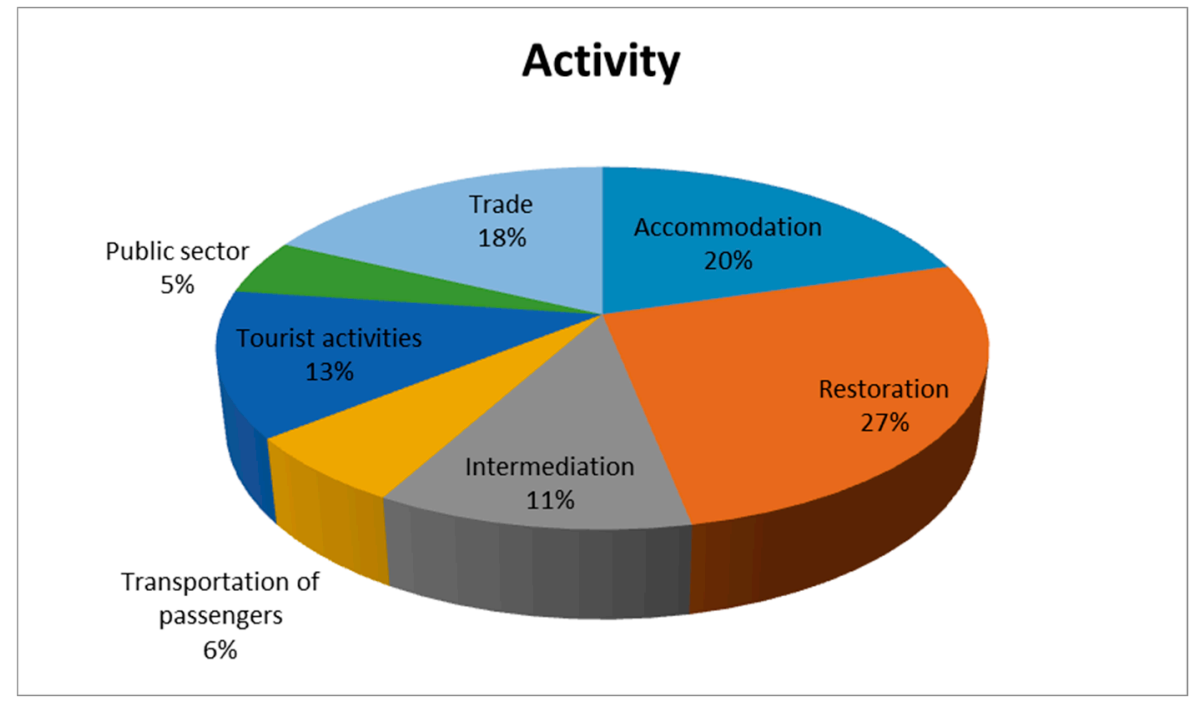

Figure 2. Sample.

The study area is representative of the main tourist areas of the archipelago of Madeira. The chosen universe represents all socio-economic activities found on Madeira Island, with Funchal and Santa Cruz as the most important municipalities to consider for the study. The probabilistic sample considered a sampling error of $5 \%$ when selecting homogeneous subgroups to include in the sampling framework described in Figure 2. Nevertheless, they were exclusive within the population in study [48] and 272 random answers to the questionnaire were the exploration target. We used the stratified random sampling technique to ensure that each socio-economic activity belonging to the strata identified in Figure 2 were covered $[48,63]$. Because partial weight contains decimal values, we used the ROUNDUP function on the Excel spreadsheet to provide absolute values for sampling size of each activity and stratum.

The response of $17.53 \%$ from the universe is considered sufficiently representative of the entire tourism sector of Madeira, because the sampling was made taking into account a certain proportionality 
of the different categories of each sector (e.g., hotel categories, or typologies of shopping, restaurants, and bars). We justify the reduction of the sample taking in the Intermediation sector (5.20\%) since hotels, transport companies, and tourist activities are the ones to carry out many of these activities.

\section{Results}

\subsection{Data Collection}

The sample observes a compact vision of the island's tourism assets, which are identified, on the one hand, as a space mainly of nature (6.66/7), of mountains and countryside (6.49), of tranquility (6.27), of adventure (5.54), and of exoticism (5.03) (Figure 3). On the other hand, Madeira is endowed with natural attractions (6.51), year-round mild climate (6.44), native hospitality (6.31), and connectivity (6.15) being among its most outstanding features. The result is an island tourist destination contrasting with the European islands that have been promoted for mass sun and beach tourism (Figure 4). For this vision, it is necessary to add that Madeira's tourism entrepreneurs consider that the archipelago has adequate freshwater resources (6.09), little traffic congestion (3.14), and a low level of pollution (2.75).

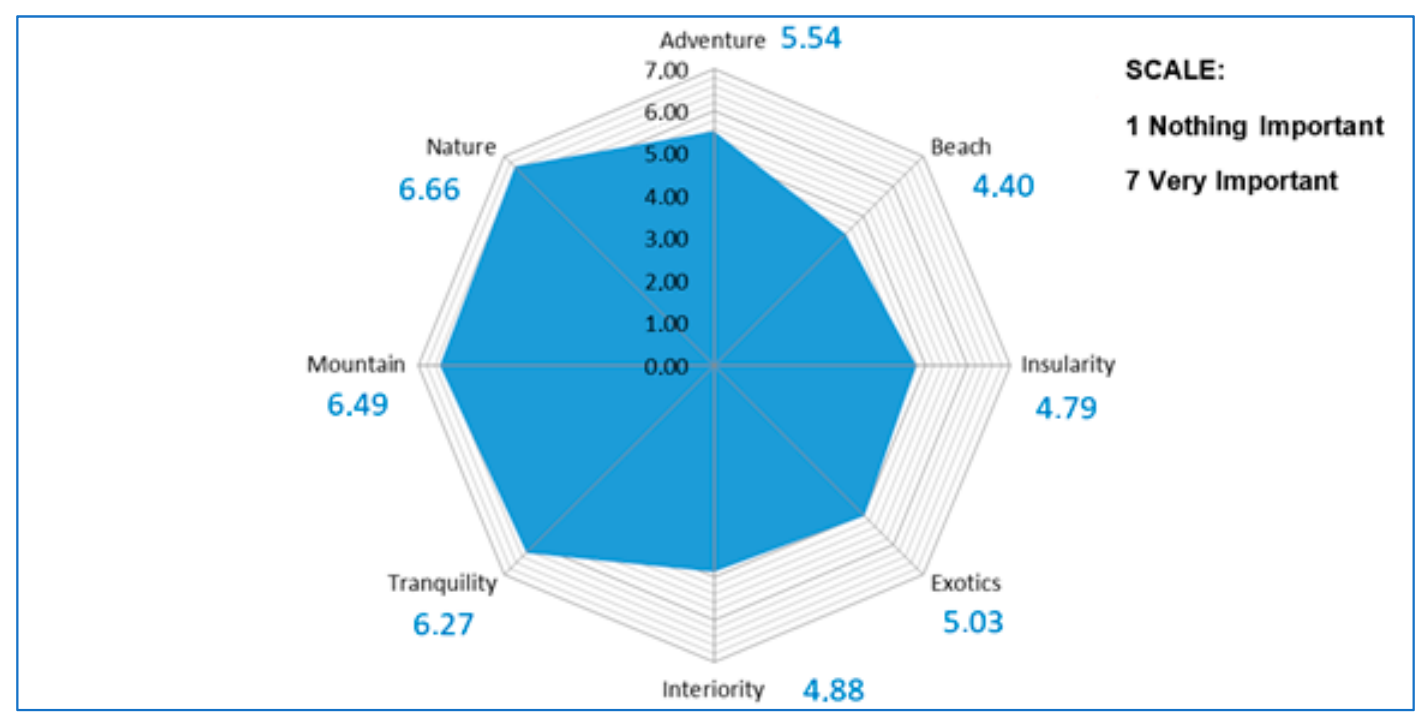

Figure 3. Mean values for the importance of Madeira as a tourist destination by the entrepreneurs.

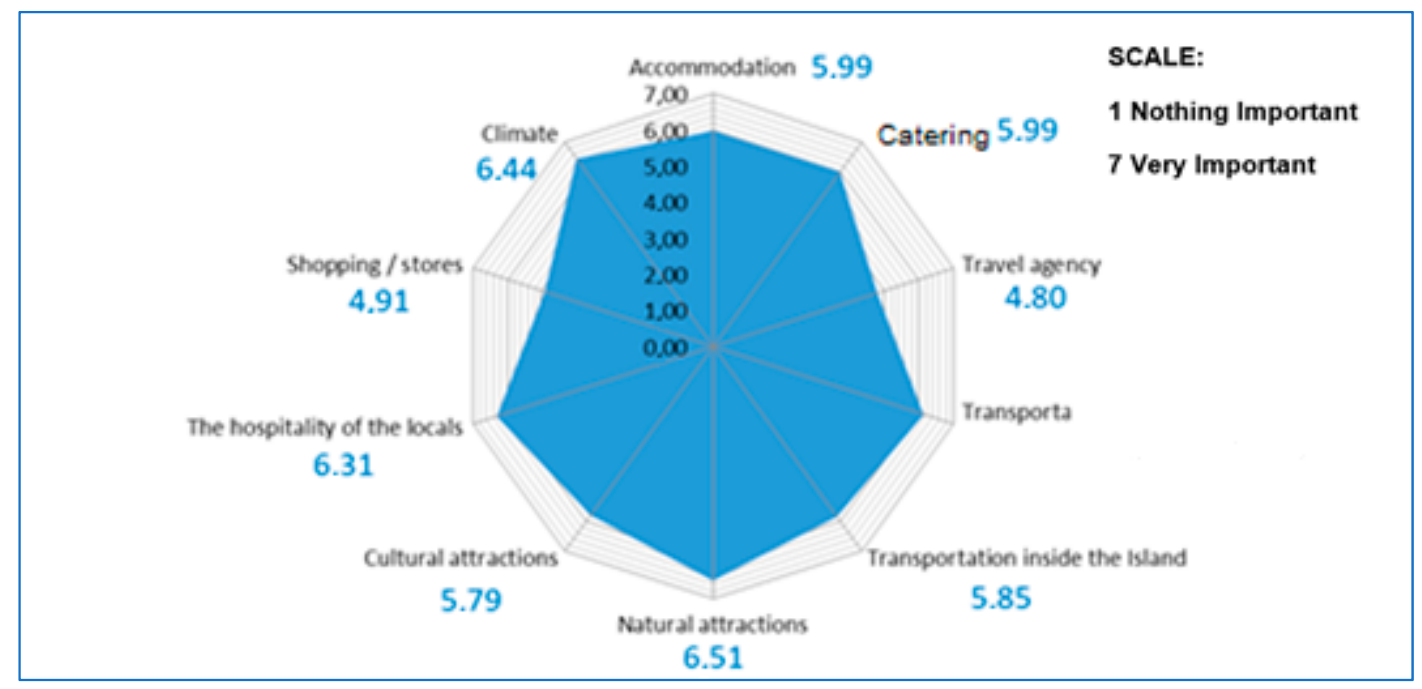

Figure 4. Mean impact in the tourist sector. 
In the case of the Canary Islands, especially, but in the rest of the major European islands as well, there are now planning movements aimed at improving the quality of the tourism products and the destination. This improvement in quality means repositioning from the traditional sun and beach model to a more sustainable, less massive, more experiential, and more personalized model. After the rapid advance of the life cycle of their products and destinations in recent decades, they are forced to restructure, a process that has not occurred in Madeira, since it has not followed this same path.

Although in Madeira, tourism entrepreneurs do not overtly adopt a slow vision of tourism, they do want to differentiate themselves from the other European islands and the tourism products they offer. More than two thirds of the sample $(67.00 \%)$ is totally or quite in agreement that they want to convey to tourists the idea that they offer a space for a more relaxed and peaceful experience (Figure 5).

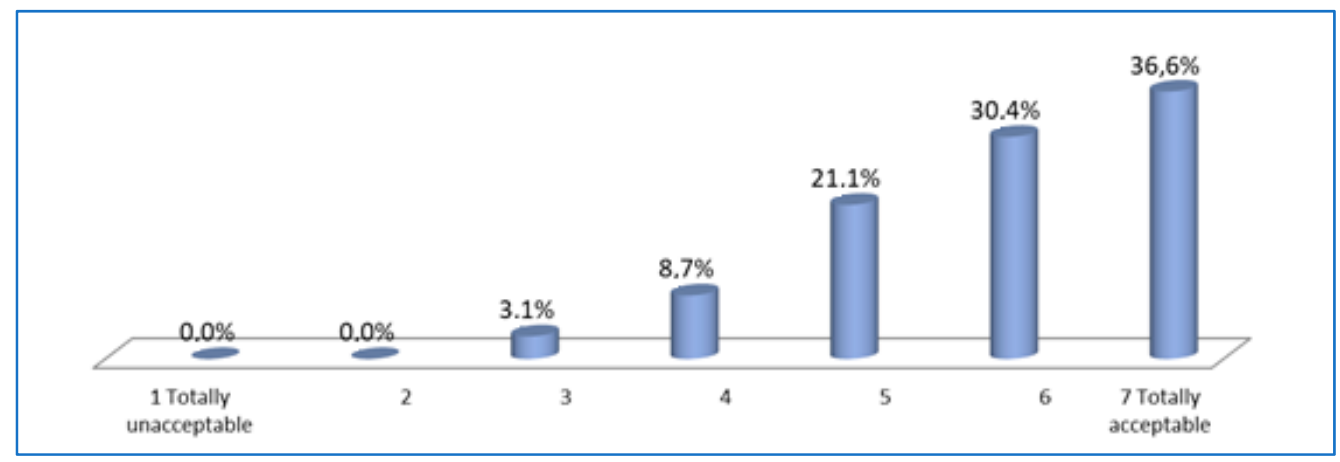

Figure 5. Experiences are intense, and time is slow.

Although most respondents consider that the island has enough room to increase the number of tourists (59.80\% completely agree, and $31.10 \%$ strongly agree), there is a common position favoring sustainability: $50.90 \%$ of the sample has the habit of completely separating waste in their companies and $36.00 \%$ does it at least $50.00 \%$ of the time (Figure 6 ).

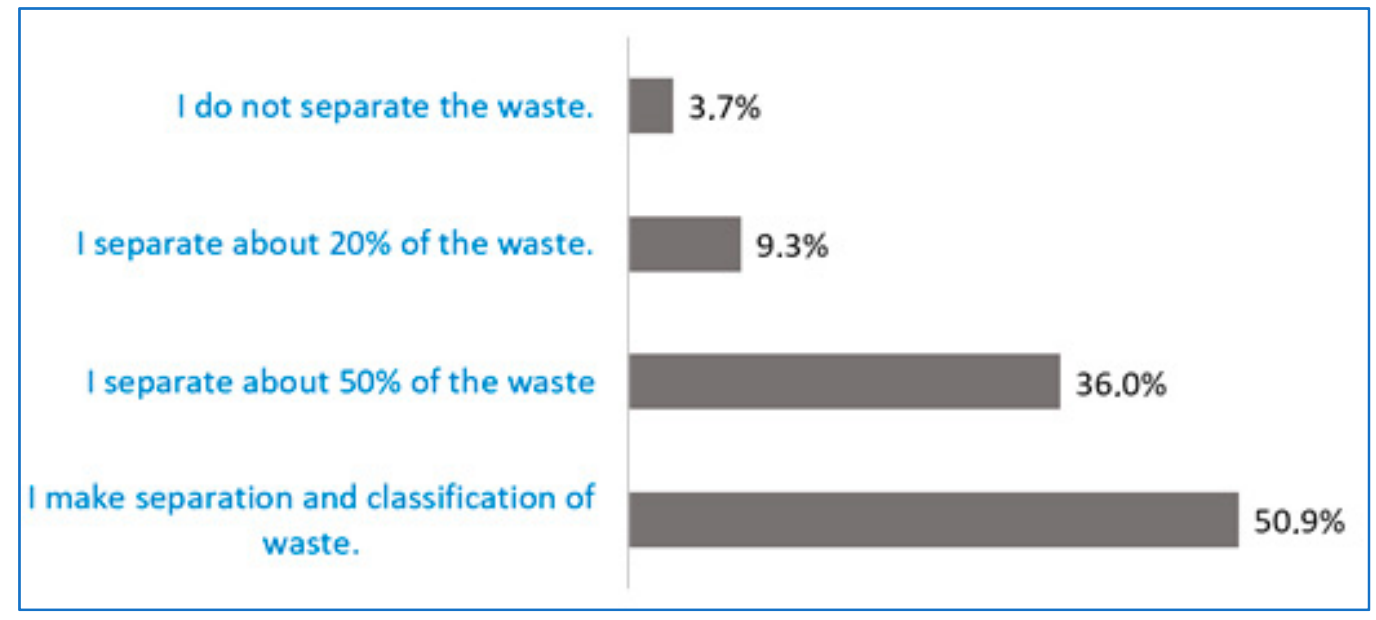

Figure 6. Circular economy.

Additionally, more than two thirds of the sample (66.50\%) unconditionally support an eco-label for the island and would adhere to it immediately, while $32.30 \%$ support it.

Tourism entrepreneurs in Madeira identify themselves with a sustainable island, considering that sustainability as a determining factor in the experience, and cooperate greatly in improving the quality of the offer. Thus, more than half of the sample $(57.10 \%)$ totally agree or agree strongly with the fact that tourists will pay more if a better experience is offered (Figure 7). 


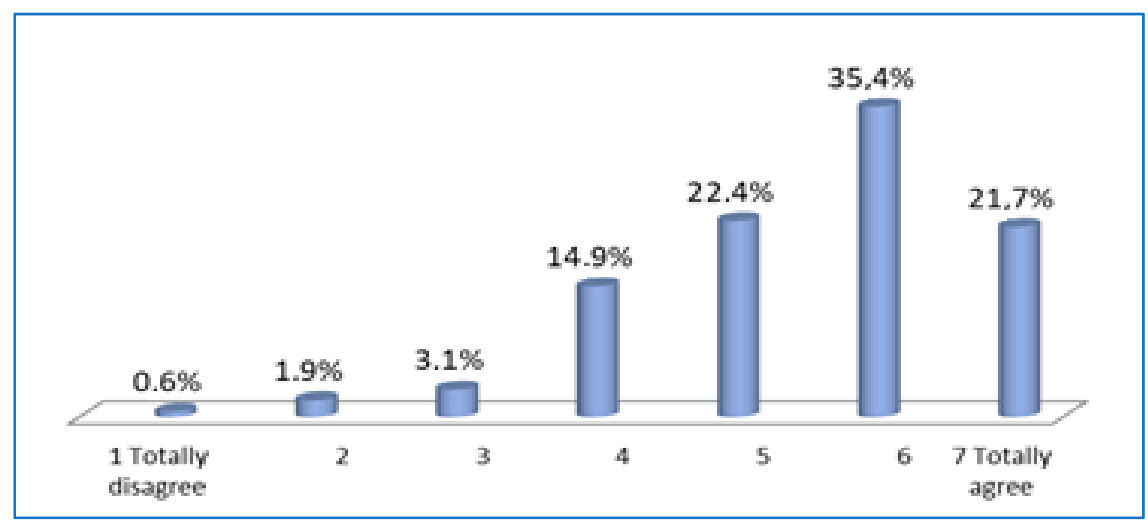

Figure 7. Tourists are willing to pay more for a better experience.

From these graphs, there are several components to be considered: (1) A vision of the territory and heritage by tourism entrepreneurs associated with nature, mountains, and tranquility; (2) a balance of the offers around the natural attractions with medium or small establishments fundamentally, and without large agglomerations; and (3) hospitality of the locals, which is among the characteristics of destinations less exposed to international traffic.

To these components, we must add the complete identification of the interviewees with a less aggressive tourism model, and with a sustainable vision thanks to the high percentage of the sample that claims to recycle its waste.

The data obtained places us before a scenario in which business owners contemplate the offer to the tourist of a highly differentiated island against other islands or other European coastal areas, where competitors are much more aggressive, overcrowded, intensive in terms of the use of territory and heritage. And it fits perfectly, as can be seen when analyzing the strategic planning model of the destination (described in Section 4.2.1). The results obtained point to an identification with slow tourism, despite the low penetration of these theories on the island.

\subsection{Hypotheses Testing}

4.2.1. H 1: The Characteristics of Madeira's Tourism Development Fit in with the Basics of Slow Tourism

\section{Analysis of the Strategic Plans for Madeira's Tourism}

The regional strategy of smart specialization for tourism in Madeira identifies Research, Development and Innovation R\&D+I as the engine for value creation in the region. However, the strategy stresses that in addition to research, crucial for developing the destination, it is essential to put the plan into practice [64]. In order to achieve the mentioned result, it is stated that in the context of tourism, the metrics outlined should follow the strategy document.

It is curious to note that, within the set of rubrics for the development of the region (objectives, areas of action, lines of action and priority activities) there are points that, interlinked, form a logical and guiding line for the development of tourism within the scope of the concept of slow tourism.

In line with slow tourism, we have identified the following:

- Objective: To invest in creative and cultural industries, natural and cultural heritage, and recreational and leisure activities, in order to directly and indirectly qualify the tourism area, encouraging the creation of qualified employment in the sector;

- Area of activity: Religious and cultural touristic circuits, nature tourism, nautical tourism, health and wellness tourism, and gastronomy and wines;

- Line of action: Implementation of initiatives promoting the urban, environmental, landscape, and social quality of the destination; 
- Priority activities: Introducing sustainability requirements to ensure the preservation of tourist attraction areas in tourism projects, including:

Developing specific tourism awareness programs for the natural, historical and cultural value of the region.

○ Developing programs aimed at introducing management mechanisms; namely, rationalization of consumption and environmental efficiency; energy efficiency; renewable energies; waste management; and good practices in the value chain.

$\bigcirc \quad$ Reassessing and confirming the repositioning of well-being and to create circuits, networks and tourist itineraries according to the repositioning of the offer to the tourist (orientation to the experience).

The Madeira Tourism Strategy 2017-2021, presented by the Regional Secretariat for Tourism Economy and Culture in 2016 [61], reveals that its mission is to differentiate and consolidate Madeira as a destination by offering quality products and services based on authenticity and genuineness, aiming at economic, social, and environmental sustainability until 2021 [65]. Therefore, we intend to highlight the potential of slow tourism to fulfill this mission.

If we follow one of the objectives presented together with the region's tourism product portfolio, which is detailed below, we show that they are in line with slow tourism drivers.

Objective 2 of the Madeira Tourism Strategy 2017-2021 document emphasizes the intention to qualify and consolidate the tourism offer-namely, to consolidate the quality of the service; support the well-received Madeira culture; and preserve and enhance the region's natural, historical; and cultural heritage [65]. Therefore, the following are identified as strategic products for the development of the region: Nature and adventure sport, cultural and scenic touring, and nautical experiences, including sports, sun, and sea [65]. Health, well-being, gastronomy, and wines are considered complementary products; the human element being the link between tourism products and visitors to the destination [65]. Therefore, we see that there is indeed potential in the region to offer slow tourism if this goal is linked to the strategic and complementary products (Figure 8).

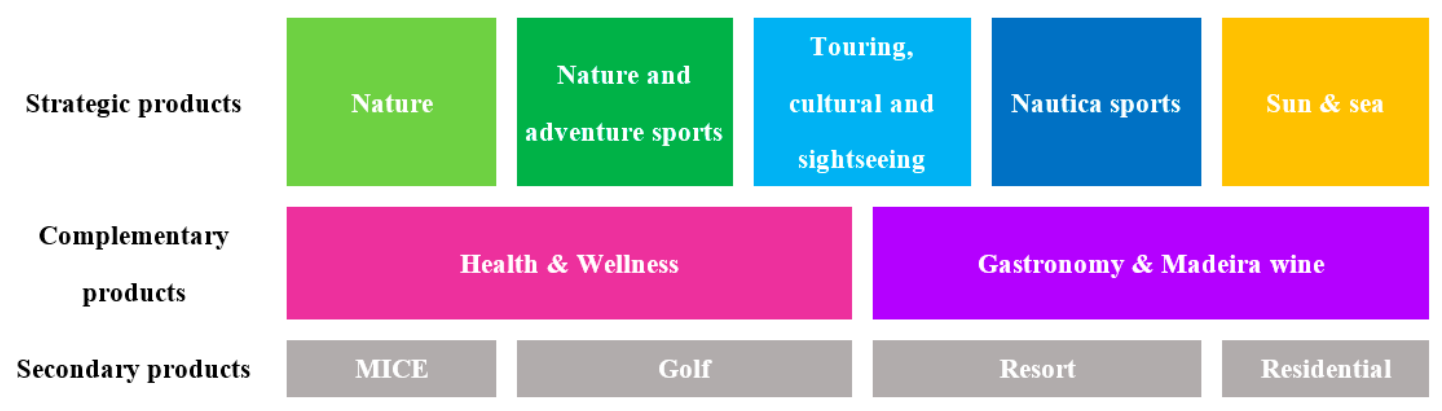

Figure 8. Portfolio of Madeira Tourist Products Source [65].

Having analyzed the global macro-trends by Funchal Commercial and Industrial Association (ACIF), in collaboration with the Klynveld Peat Marwick Goerdeler (KPMG), the Tourism Strategic Document of the Autonomous Region of Madeira (RAM) [65] mentions that more and more tourists are seeking the authentic, refusing the artificial, searching for well-being, growing in environmental awareness, and as consumers, they are increasingly looking for the offer of experiences that encompass all of these components.

In this sense, the mission of the region of Madeira is to provide visitors with a range of innovative, diversified and authentic experiences capitalizing upon peoples' talent, the essence of local values and traditions. Doing so would, consequently, accelerate economic, environmental, and social development of the archipelago [65]. 
Considering that this mission is in line with slow tourism, we have identified that one of the strategic objectives emphasizes the phenomenon we are defending here, namely Objective 5: "To contribute to the preservation and enhancement of the natural, historical and cultural heritage of the Region." The critical success factors in achieving this goal are the recognition of environmental and landscape quality of urban and rural areas, the preservation of protected areas and the richness of biodiversity and geodiversity, without ignoring the tourists' awareness of the need to support the natural, historic heritage, and cultural development of the region [65] (Figure 9).

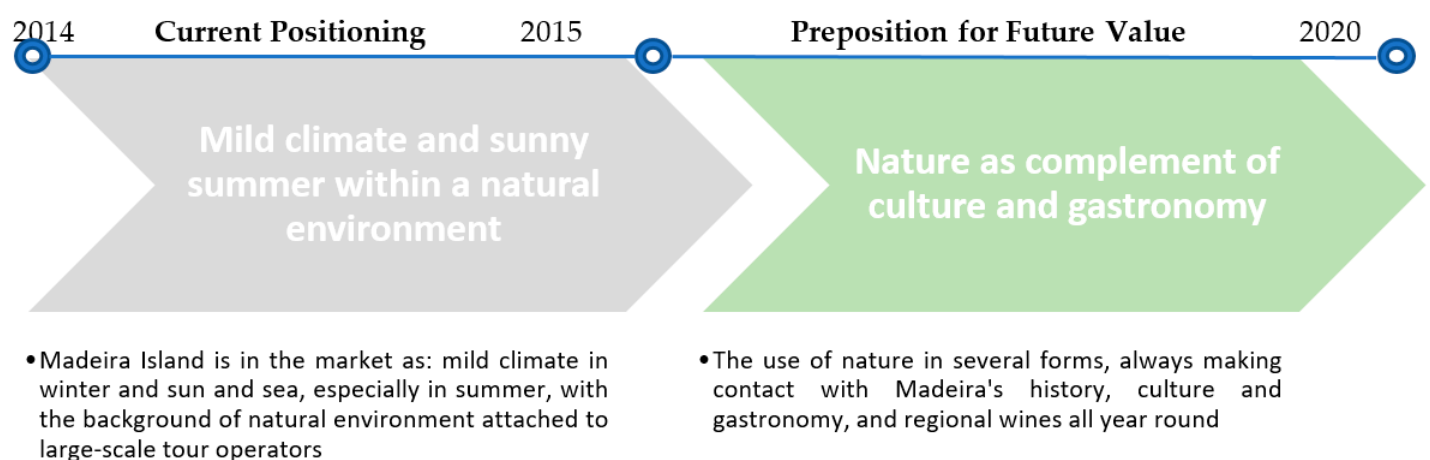

Figure 9. Scenery for the Madeira's strategic evolution. Source: Adapted from [65].

Evolution of Overnight Stays

Excepting the years 2008 to 2010, in which there was a slight setback of tourism likely due to the global economic crisis in that period, the trend of overnight stays in Madeira since 2004 has been upward but with mild growth (Figure 10).

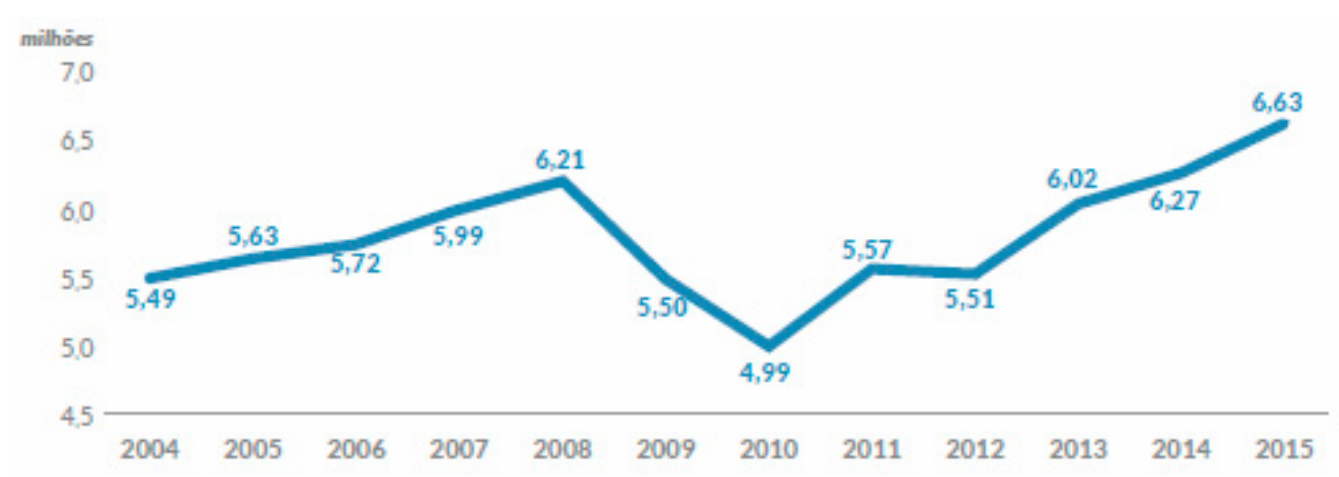

Figure 10. Overnight stays in Autonomous Region of Madeira (RAM) hotels (million) Source: [60].

Madeira Benchmarking

A benchmarking of a series of ratios has been made between the main European islands (the Canary Islands, Sicily, Mallorca, Corsica, Malta, and Cyprus) with Madeira. For a better knowledge of the position of Madeira, the Azores and Cape Verde were added (Table 2).

The number of tourists visiting Madeira is much lower than that of the large Mediterranean islands offering sun and beach—the Canary Islands, Sicily, Mallorca, Corsica, and Cyprus. The tourist ratio per square meter is 1792.3 in Madeira, below that of the Canary Islands (1999.1), whose territory is almost ten times larger; below that of Mallorca Island (2050.4), which is four times larger; and below that of Malta (6292.5), with less than half the territory. It exceeds only that of Corsica (890.5), Sicily (524.8), Cyprus (394.7), the Azores (253.3) and Cape Verde (177.7). 
Table 2. Benchmarking of Madeira with respect to the large European islands.

\begin{tabular}{|c|c|c|c|c|c|c|c|c|c|}
\hline Study Group & $\begin{array}{c}\text { Madeira } \\
\text { Autonomous Region }\end{array}$ & $\begin{array}{l}\text { Canary } \\
\text { Islands }\end{array}$ & Cape Verde & Mallorca & Corsica & Cyprus & $\begin{array}{c}\text { Azores } \\
\text { Autonomous } \\
\text { Region }\end{array}$ & Malta & Sicily \\
\hline Total number of tourists & $1.435 .700 \mathrm{a}, \mathrm{b}$ & 14.980 .000 & $716.775^{\mathrm{a}, \mathrm{b}}$ & 10.920 .237 & 7.730 .000 & 3.652 .073 & $594.300^{\mathrm{a}, \mathrm{b}}$ & 1.988 .447 & $13.495 .491^{\mathrm{i}}$ \\
\hline $\mathrm{Km}^{2}$ & 801 & 7.493 & 4.033 & 3.640 & 8.680 & 9.251 & 2.346 & 316 & 25.711 \\
\hline Average occupancy rate & $71,4 \%^{c} 78,4 \%{ }^{a, j}$ & & $69 \%$ a,f & $79,50 \%$ & $48,80 \%$ & $71,3 \%^{c}$ & $50,9 \%{ }^{a, c} 62,2 \%^{a, j}$ & $64,50 \%$ & \\
\hline No. of hotel rooms & $8.498^{\mathrm{a}}$ & & $9.541^{\mathrm{a}}$ & 81.216 & 12517 & 41080 & & & \\
\hline No. of hotel beds & 29.118 & 235.313 & $15.872^{a}$ & 155.021 & $756.500^{d}$ & $55.202^{a}$ & $9.184^{a}$ & 33.147 & 121.032 \\
\hline $\begin{array}{l}\text { Seasonality months } \\
\text { (months with more than } \\
75 \% \text { occupancy in hotels) }\end{array}$ & Jul-Set ${ }^{\mathrm{f}, \mathrm{h}}$ & $\mathrm{Ago}^{\mathrm{a}, \mathrm{k}}$ & & Jun-Set $^{\mathrm{i}}$ & Ago e Set & Mai-Out ${ }^{\mathrm{e}}$ & $\mathrm{Jul}^{-A g o}{ }^{\text {a }}$ & Jul-Ago a & \\
\hline $\begin{array}{l}\text { Months of Seasonality } \\
\text { (months with more than } \\
50 \% \text { occupancy in hotels) }\end{array}$ & Jan-Nov ${ }^{f}$ & Mar-Nov a,k & & Fev-Nov & Mai-Out & Mai-Out ${ }^{\mathrm{e}}$ & Abr-Set ${ }^{a}$ & Mar-Nov ${ }^{a}$ & \\
\hline Number of residents & 254.876 & $2.108 .121^{a}$ & 539.56 & 402.949 & $330.354^{\mathrm{g}}$ & 1.170 .000 & 245.283 & 436.947 & $5.056 .641^{a}$ \\
\hline
\end{tabular}

Notes: (a) 2017; (b) Number of guests (value of approximation to the number of tourists; (c) BOR - Bed occupancy rate; (d) Number of daily beds multiplied by the number of days in the month; (e) Referred to as seasonal months by the Cyprus Tourism Market (p.7); (f) Based on BOR; (g) Provisional date; (h)2015; (i) 2010; (j) Net Occupancy Rate - Room; (k) Degree of occupancy by number of beds. 
The number of hotel beds is also well below what is found in the Canary Islands, Mallorca, Corsica, Cyprus, and Sicily; similar to Malta; and above what is found in the Azores and Cape Verde. Together with Mallorca and Cyprus, Madeira's hotel occupancy is among the highest of the European islands, exceeding $70.00 \%$. Madeira's ratio of tourists per inhabitant is quite favorable: 5.6 compared to Mallorca (27.1), Corsica (23.3), Cape Verde (13.1), and the Canary Islands (7.1). It is, however, higher than that of Malta (4.5), Cyprus (3.1), Sicily (2.6) and the Azores (2.4). This benchmarking puts Madeira in a good position for sustainable growth.

As a result of the analysis of secondary sources and the benchmarking that has been carried out, we can validate that the characteristics of Madeira tourism development fit in with the basics of slow tourism.

4.2.2. H2: There Is No Openly Favorable Attitude toward Slow Tourism among Tourism Entrepreneurs in Madeira

As we can see in Figure 11, the survey responses indicated that our hypothesis $\mathrm{H} 2$ does not hold true. In contrast, the opposite hypothesis can be proven, as the following statistical proportion test shows that $\mathrm{H} 2^{\prime}$ : There is no openly favorable attitude toward slow tourism among tourism entrepreneurs in Madeira. This figure expresses the conviction of the Madeira entrepreneurs that the island's environment produces good experiences and the rhythm of tourism is slower.

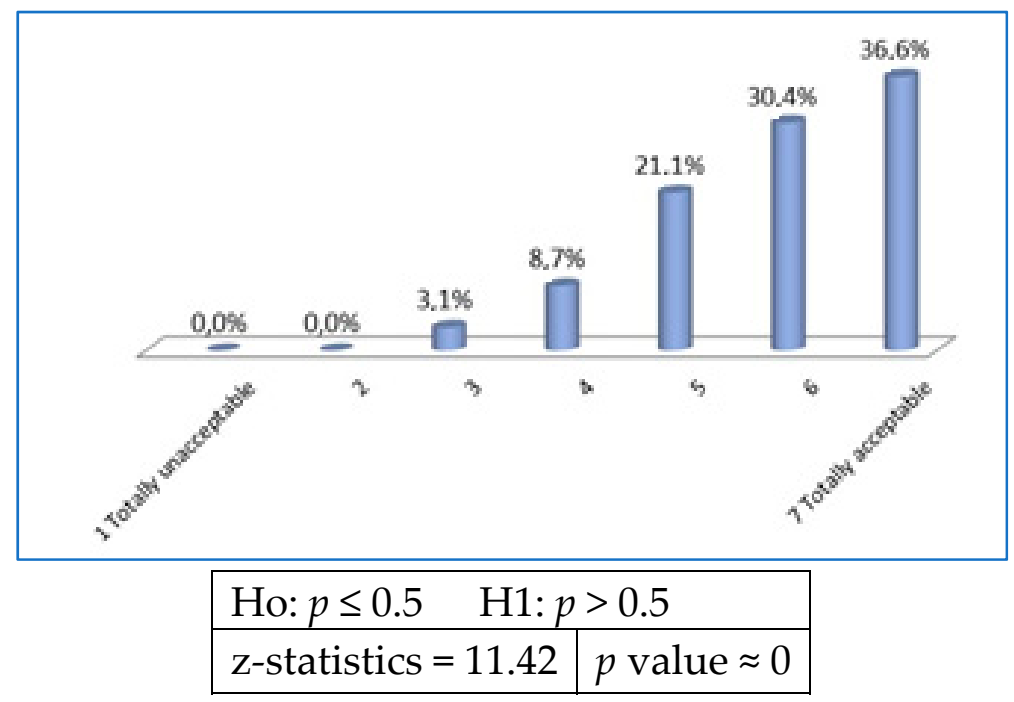

Figure 11. Great experience and slower time, unlike in the sun and beach.

Considering responses 1, 2, and 3 for non-support of $\mathrm{H} 2$ and 5, 6, and 7 supporting $\mathrm{H} 2$ : Sample proportion in favor of $\mathrm{H} 2: 96.60 \%$ (142), in front of $3.40 \%$ (4)

Thus, we concluded that the sample considered that the island produces great experiences and tourist time is slower, contrary to what happens in other European island destinations. Therefore, the opposite of $\mathrm{H} 2$ is supported.

4.2.3. H3: Tourism Providers on the Island Would Be Willing to Carry out This Model of Tourism and Apply It

To prove this hypothesis, the questions shown in Figures 12-14 were considered and for each question, a proportion test was computed. In all questions, we prove rejection of the null hypothesis in favor of the alternative hypothesis, which indicates the affirmation of $\mathrm{H} 3$. 


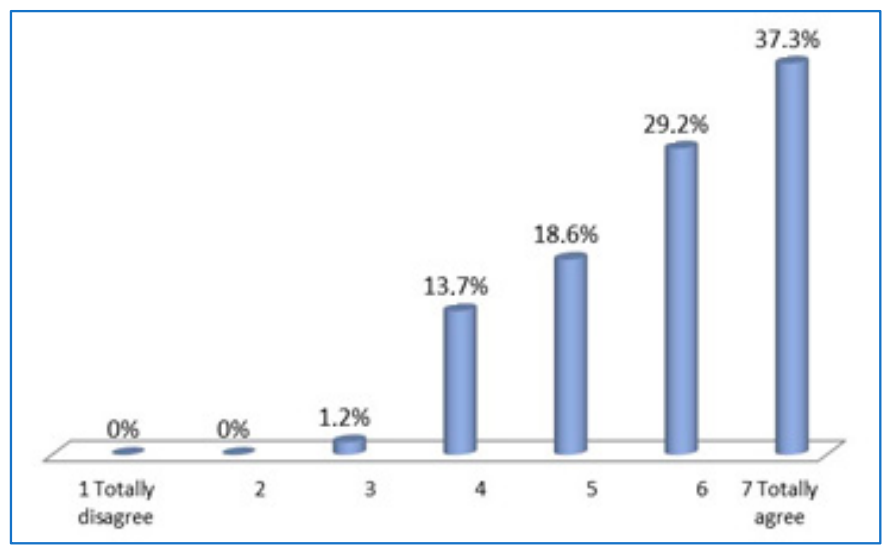

$$
\begin{array}{|l|l|}
\hline \text { Ho: } p \leq 0.5 \quad \text { H1: } p>0.5 \\
\hline z \text {-statistics }=11,45 & p \text { value } \approx 0 \\
\hline
\end{array}
$$

Figure 12. Would you support the identification of Madeira with an eco-label in which the island's tourism businesses could join?

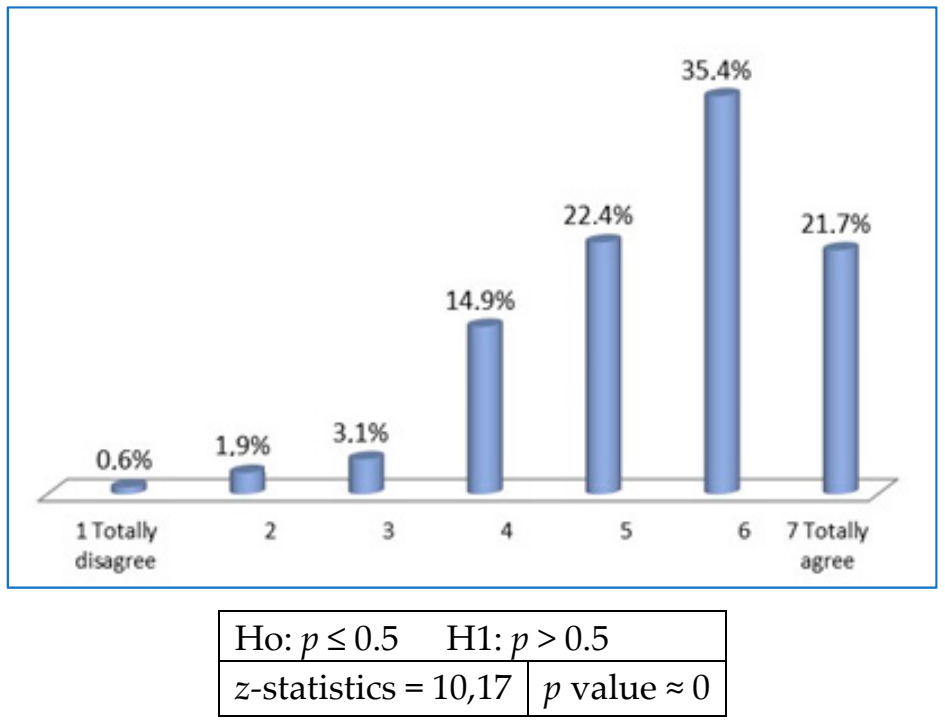

Figure 13. Tourists are willing to pay more for a better experience.

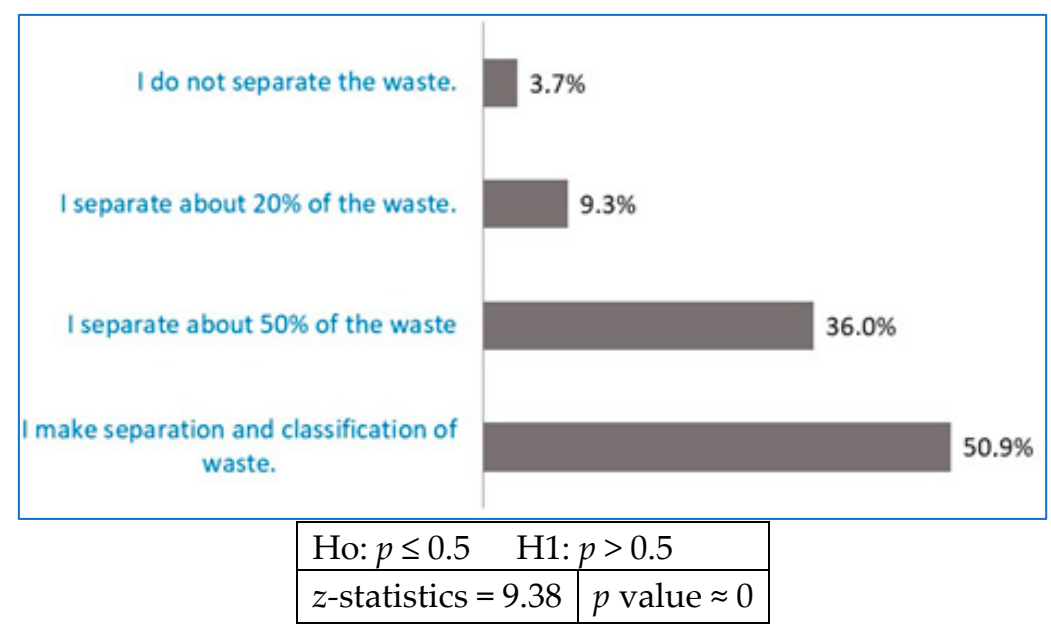

Figure 14. Circular Economy. 
For the question in Figure 12, considering responses 1, 2, and 3 not supporting H3 and 5, 6, and 7 supporting H3 and dropping response 4: Sample proportion in favor of H3: 98.60\% (137), leaving $1.40 \%$ (2). We define $\mathrm{p}=$ "Percentage of tourism providers supporting the idea of Madeira being identified with an eco-label in which the island's tourism businesses could join."

We could then conclude that the percentage of support for the identification of Madeira with an eco-label in which the island's tourism businesses could join is greater than $50.00 \%$.

For the question in Figure 13, considering responses 1, 2, and 3 for non-support of H3 and 5, 6, and 7 supporting H3 and dropping response 4: Sample proportion in favor of H3: $93.40 \%$ (128) in contrast to $6.60 \%$ (9). We define $p=$ "Percentage of tourists willing to pay more for a better experience."

We can then conclude that the percentage of tourists willing to pay more for better experiences is greater than $50.00 \%$. For the question in Figure 14, we considered the two first responses as non-support of H3 and the two last responses supporting H3. Sample proportion in favor of H3: $87.00 \%$ (140), leaving $13.00 \%$ (21) opposed. We define $\mathrm{p}=$ "Percentage of businessmen supporting the circular economy".

We then concluded that the percentage of entrepreneurs supporting the circular economy is greater than $50.00 \%$.

With these three questions and their statistical test, we concluded in favor of hypothesis 3.

\section{Discussion}

A destination's insularity and ultra-peripheral location are factors that usually reduce tourist overcrowding. Such is the case for Madeira, the Azores, and Cape Verde. To this we must add, as it happens especially in the first one, a smaller dimension of the island with a low density of population. In contrast, Sicily, Mallorca, Corsica, Malta, and Cyprus have benefited from centrality, developing traditional sun and beach tourism. However, these restraints on overcrowding are not a sine qua non condition for the existence or survival of a sustainable tourism model. The Canary Islands, for example, is an insular and ultra-peripheral territory, yet it has joined the mass tourism of traditional sun and beach.

Therefore, when analyzing the case of Madeira, a definitive factor emerges that unleashes the tourism management model: The strong resistance of the island's agents to developing an invasive tourism that would throw off the balance of territory and heritage. While the large European islands were the protagonists of the tourist expansion of the last fifty years, Madeira opted for more sustainable formulas. From 1990-2000, when these major destinations were forced to promote policies that reduce tourist flows and pressure on the territory, Madeira was able to increase them without destroying the existing environmental balance. In this way, Madeira's tourist policies have been aimed at preserving the model.

This strong resistance to depredating the island, to creating an oversupply for a mass audience, is found in most of the public documents provided: Decision on the portfolio [48,61,62,65-67]; and approach to a new paradigm $[68,69]$. The vision of the agents (the public sector) coincides with the slow tourism model, which can be seen in the results of our survey of the private sector $[1,12,15]$. It is not a movement of resistance, as happened in Calviá $[16,70]$ or Lanzarote [17,71] against degeneration of the territory produced by the over-touristification of the territory, but rather an impulse to keep Madeira away from the over-exploitation of tourism $[4,6,7,44]$. In this competitive scenario-with the attraction of the islands as a background - there is a parallel between the development model promoted and the main contents of the slow tourism movement, which are expanding in many places. The results of our survey of tourism entrepreneurs confirms this detail. This public sees Madeira as a destination of nature, mountains, tranquillity, cultural space, authenticity, adventure, and numerous local products $[2,8,37,38,42,46,47,72-82]$. It considers the island as self-sufficient in water resources. It shows important advances in the application of circular economic processes. The island has low traffic congestion and pollution. In addition, there is a push toward the creation of an eco-label identifying the whole island. In this way, Madeiran entrepreneurs are aware of having a territory and heritage 
with low tourism pressure. Therefore, they consider that the number of tourists can continue to grow, but within criteria of sustainability of the territory. When comparing this model with the values of slow tourism, we find three aspects to consider.

1. The slow tourism movement was born as a change in the concept of travel, as an alternative and reaction to mass tourism, offering instead the authentic, the local and the cultural, as a driver of zero-kilometer products, the sustainable, and the quality of the experience. In the case of Madeira, it has originated not as the result of a reactive movement but rather as a natural sequence of the interest of the main actors, supported by Madeira's insularity and ultra-periphery. This study reflects the vision of entrepreneurs as the first guarantors of the model.

2. It is true that the ideas of slow tourism originated outside of Madeira, but when compared with the vision of entrepreneurs, it turns out that there is a significant alignment. In similar cases of destinations where tourism development has been low or incipient, whether island territory or not, it can be deduced that the approach to the values of slow tourism accelerates the construction of a slower and more sustainable model. It is not a revision of the model, but an impulse to offer the same from the beginning.

3. Entrepreneurs are convinced that tourists are willing to pay more for a better experience. In favor of Madeira's tourism offer is the fact that the island has not been forced to rehabilitate either its territory or its heritage since it did not undergo a mass tourist invasion. Therefore, in this type of destination there is no cost for the change of image; instead, the slow tourism model develops or advances positively.

\section{Conclusions and Limitations}

\subsection{Conclusions}

The main conclusions of this study are the following:

- Slow tourism is a movement that brings together a set of distinct characteristics with respect to the life cycle of mass tourism that began in the 1960s. These characteristics are related to a different concept of travel and visits: Less rapidity and more tranquility; seeking to discover the small, the peculiar, and the personal; an alternative way of approaching routes, local culture, and zero-kilometer products; keen awareness and care of the environment; and emphasis on the search for authentic experiences.

- In line with slow tourism, new types of tourism are developed and incorporated as new motivations for a trip: Adventure, agritourism, cruises, ecotourism, education, indigenous, medical, musical, religious, volunteering, sport tourism, trekking, running, birdwatching, and so forth.

- Slow tourism's development in a given destination offers opportunities to improve its position as a tourist attraction and increase its economic income, especially when assuming that the tourist is willing to pay more for a superior experience.

- The path of slow tourism demands a planning model radically different from the life cycle stage of mass tourism.

- A destination does not need to reach an advanced stage of the life cycle and be forced to react by proposing alternative models of tourism management. A slower, more sustainable tourism can be chosen, based on an endogenous impulse, for advantages such as its low exploitation of general resources. Such is the case for Madeira: The island has adopted the same convictions without the trauma of having been forced to abruptly apply the tourism brakes and remediate damage from mass tourism. The opinions of Madeiran tourism entrepreneurs confirm this sustainable endogenous vision, even without their having explicitly learned the values of slow tourism.

- Thanks to the happy confluence of the endogenous impulse of tourism planning with the ideas of slow tourism, the destinations, insular or not, will assimilate the sustainable models more quickly. 
This opens the way for more rapid tourism development, within the criteria of sustainability, for emerging destinations. In this sense, Madeira can be offered as a remarkable case.

- In the majority opinion of our sample, tourists are willing to pay more for a better experience. It is interesting to find this conviction among the entrepreneurs of a destination. However, for this assertion to be verified, it would have to be compared with the opinions of consumers who choose to accept offers with different intensity, quality of experience, and price.

\subsection{Limitations}

The lack of empirical verification as to whether tourists are willing to pay more for a better experience is one of the limitations of the study. It has been found that entrepreneurs believe this. But to confirm this, the reaction of a sample of consumers to tourist offers of different intensity, quality, and price should be analyzed. A second limitation is that, despite the effort that has been made in the benchmarking of Madeira with respect to a number of European islands from secondary sources, further investigation would make it possible to better compare the variables of the numbers of tourists, local residents, population density, and accommodations and tourist experiences on offer in general. This last approach is presented as a line of research to be developed.

Author Contributions: J.-F.V., conceived the original idea for the paper and wrote much of the original text. He was the corresponding author and replied to all questions and suggestions made by the reviewers, likewise, he organized the review process among the authors. L.M. developed the methodology for fieldwork and organized the data. He was involved in the reviewing process, including text improvement and on behalf of the corresponding author, answering MDPI. S.C.F.V. provided some of the literature review and data for benchmarking Madeira island with direct competitors. She drafted the first versions of the paper and designed the questionnaires developed for this study. R.S. did the state of art about slow tourism and assisted in the fieldwork.

Funding: This work was supported by the Operational Program of the Autonomous Region of Madeira 2014-2020 (Portaria $n^{\circ}$ 92/2015) under Grant M14-20-01-0145- FEDER-000007, “Tourism Project: Characterization, Impact and Sustainability of Madeira Tourism".

Conflicts of Interest: No potential conflict of interest was reported by the authors.

\section{References}

1. Aguiló, E.; Alegre, J. La madurez de los destinos turísticos de sol y playa. El caso de las Islas Baleares. Papeles Econ. Española 2004, 102, 250-270.

2. Marson, D. From mass tourism to niche tourism. In Research Themes for Tourism; Robinson, P., Heinttmann, S., Dieke, P., Eds.; CAB IInternational: Wallingford, UK, 2011; pp. 1-15.

3. Dickinson, J.; Lumsdon, 1. Slow Travel and Tourism; Earthscan: London, UK, 2010; 232p, ISBN 978-1-84971-113-5.

4. Heitman, S.; Robinson, P.; Povey, G. Slow food, cities and Slow Tourism. In Research Themes for Tourism; Robinson, P., Heitman, S., Dieke, P., Eds.; CABI International: Wallingford, UK, 2011; pp. 114-128.

5. Lowry, L.L.; Back, R.M. Slow food, Slow Tourism \& sustainable practices: A conceptual model. In Sustainability, Social Responsibility and Innovation in Hospitality-Tourism; Parsa, H.G., Narapareddy, V., Segarra-Ona, J., Chen, R.J.C., Eds.; Apple Academic Press: Palm Bay, FL, USA, 2015; pp. 71-89.

6. Aguiló, E.; Alegre, J.; Sard, M. The persistence of the sun and sand tourism model. Tour. Manag. 2005, 26, 219-231. [CrossRef]

7. Parasuraman, A.; Zeithalm, V.A.; Berry, L.L. SERVQUAL: A Multiple-item Scale for Measuring Consumer Perceptions of Service Quality. J. Retail. 1988, 64, 12-40.

8. Georgic, G.; Bulin, D.; Dorobantu, M.R.; Stefania, B.; Nistoreanu, P. Slow Movement as an Extension of Sustainable Development for Tourism Resources: A Romanian Approach. In Proceedings of the Conference: 20th IBIMA Conference, Special Edition, Kuala Lumpur, Malaysia, 25-26 March 2013.

9. Lowry, L.L.; Lee, M. CittaSlow, slow cities, slow food: Searching for a model for the development of Slow Tourism. In Proceedings of the Travel \& Tourism Research Association, 42nd Annual Conference: Seeing the Forest and the Trees-Big Picture Research in a Detail- Driven World, London, ON, Canada, 19-21 June 2011.

10. Clancy, M. Conclusion: The promises and pitfalls of slow. In Slow Tourism, Food and Cities; Clancy, M., Ed.; Routledge: London, UK, 2018; 248p. 
11. Williams, P.W.; Ponsford, I.F. Confronting tourism's environmental paradox: Transitioning. for sustainable tourism. Futures 2009, 41, 396-404.

12. Ferreira, P.F.; Seabra, C.; Paiva, O. Slow cities (Cittaslow): Os espaços urbanos do movimento slow. Rev. Tur. Desenvolv. 2014, 21/22, 191-193.

13. Conway, D.; Timms, B. Are Slow Travel and Slow Tourism Misfits, Compadres or Different Genres? Tour. Recreat. Res. 2012, 37, 71-76.

14. Fullagar, S.; Markwell, K.; Wilson, E. Slow Tourism: Experiences and Mobilities; Channel View Publications: Bristol, UK, 2012; 248p, ISBN 978-1845412807.

15. Babou, I.; Callot, P. $\mathrm{CO}_{2}$ et tourisme: Vers de nouvelles segmentations? In Proceedings of the 12èmes Journées de Recherche en Marketing de Bourgogne, CERMAB, Dijon, France, 8-9 November 2007.

16. Lumsdon, L.M.; McGrath, P. Developing a conceptual framework for slow travel: A grounded theory approach. J. Sustain. Tour. 2011, 19, 265-279. [CrossRef]

17. Matos, R. Can Slow Tourism Bring New life to Alpine Regions. In The Tourism and Leisure Industry Shaping the Future; Weirmair, K., Mathies, C., Eds.; Haworth Hospitality Press: Binghamton, NY, USA, 2004; pp. $93-103$.

18. Dodds, R. Sustainable Tourism and Policy Implementation: Lessons from Case of Calviá, Spain. Curr. Issue Tour. 2008, 10, 296-322. [CrossRef]

19. Valls, J.F.; Tuñon, F.J.; Calero, P.; Ramos, J.M.; Prats, F. Un marco estratégico para fortalecer el sistema económico insular, compatible con la contención del crecimiento turístico en Lanzarote, Life Lanzarote, Cabildo de Lanzarote. 2004, 70p. Available online: http://www.cabildodelanzarote.com/ecotasa/des12.pdf (accessed on 22 March 2018).

20. Parasuraman, A.; Zeithalm, V.A.; Berry, L.L. A Conceptual Model of Service Quality and its Implications for Future Research. J. Mark. 1985, 49, 41-50. [CrossRef]

21. Bojanovic, D.C.; Rosen, L.D. Measuring service quality in restaurants: An application of the SERVQUAL instrument. Hosp. Res. J. 1994, 1, 3-14.

22. Gronroos, C. A Service Quality Model and its Marketing Implications. Eur. J. Mark. 1984, 18, 36-44. [CrossRef]

23. Getty, J.M.; Thompson, K.N. The relationship between Quality, Satisfaction, and Recommending Behavior in lodging decisions. J. Hosp. Leis. Mark. 1995, 2, 3. [CrossRef]

24. Gallarza, M.G.; Gil, I. Value dimensions, perceived value, satisfaction and loyalty: An investigation of university student's travel behavior. Tour. Manag. 2006, 27, 437-452. [CrossRef]

25. Patton, M.; Stevens, P.; Knutson, B.J. Internationalizing LODGSERV as a Measurement Tool: A Pilot Study. J. Hosp. Leis. Mark. 1994, 2, 39-55. [CrossRef]

26. Fick, G.R.; Ritchie, J.R.B. Measuring service quality in the travel and tourism industry. J. Travel Res. 1991, 30, 2-9. [CrossRef]

27. Otto, J.E.; Ritchie, J.R.B. Exploring the quality of the service experience: A theoretical and empirical analysis. Adv. Serv. Mark. Manag. Res. Pract. 1995, 4, 37-61.

28. Holbrook, M.B.; Hirschman, E.C. The experiential aspects of consumption: Consumer fantasies, feelings and fun. J. Consum. Res. 1982, 9, 132-140. [CrossRef]

29. Havlena, W.J.; Holbrook, M.B. The varieties of consumption experience: Comparing two typologies of emotion in consumer behavior. J. Consum. Res. 1986, 13, 394-404. [CrossRef]

30. Mannell, R.C.; Iso-Ahola, S.E. Psychological nature of the leisure and tourism experience. Ann. Tour. Res. 1987, 14, 314-331. [CrossRef]

31. Dunkan, E.; Fanderl, H.; Maffei, K. McKinsey \& Company, Designing and Starting up a Customer-Experience Transformation. 2016. Available online: https://www.mckinsey.com/business-functions/operations/ourinsights/designing-and-starting-up-a-customer-experience-transformation (accessed on 17 March 2018).

32. Planta. Pirámide de Experiencias. 2010. Available online: http://planta18.com/es/piramide-de-experiencias (accessed on 16 March 2018).

33. Schmitt, B.H. Customer Experience Management; John Wiley \& Sons: Haboken, NJ, USA, 2003; 256p, ISBN 978-0-471-23774-7.

34. Pine, J.; Gilmore, J.H. The Experience Economy; HBR: Cambridge, MA, USA, 1998; pp. 97-105. Available online: https://www.researchgate.net/publication/299292969_The_Experience_Economy (accessed on 12 March 2018). 
35. Valls, J.F. Customer-Centricity: The New Path to Product Innovation and Profitability; Cambridge Scholars Publishing: Newcastle upon Tyne, UK, 2018; 145p.

36. Dickinson, J.; Lumsdon, M.; Robbins, D. Slow travel: Issues for tourism and climate change. J. Sustain. Tour. 2011, 19, 281-300. [CrossRef]

37. Caffyn, A. Advocating and Implementing Slow Tourism. Tour. Recreat. Res. 2012, 37, 77-80. [CrossRef]

38. Miretpastor, L.; Peiró-Signes, Á.; Segarra-Oña, M.; Mondéjar-Jiménez, J. The slow tourism: An indirect way to protect the environment. In Sustainability, Social Responsibility and Innovations in Tourism and Hospitality; Parsa, H.G., Ed.; Apple Academic Press: Oakville, ON, Canada, 2015; pp. 317-339.

39. Oh, H.; Assaf, A.G.; Baloglu, S. Motivations and Goals of Slow Tourism. J. Travel Res. 2014, 55, $205-219$. [CrossRef]

40. Molz, J. Representing pace in tourism mobility's: Staycations, Slow Travel and The Amazing Race. J. Tour. Cult. Chang. 2009, 7, 270-286. [CrossRef]

41. Gosar, A. Il turismo in Slovenia. Le pagine di Risposte Turismo. 2014. Available online: http://www. risposteturismo.it/Public/lePaginediRT/uno2014_lePaginediRT_A.Gosar.pdf (accessed on 25 March 2018).

42. Malta Tourism Authority. Tourism in Malta. Facts and Figures 2016. Report 2017. Available online: http://www.mta.com.mt/research (accessed on 22 April 2018).

43. Özdemir, G.; Çelebi, D. Exploring dimensions of slow tourism motivation. Anatolia Int. J. Tour. Hosp. Res. 2018, 29, 540-552.

44. McGrath, P.; Sharpley, R. Slow Tourism, Food and Cities: Pace and the Search for the "Good Life". In Slow Tourism, Food and Cities: Pace and the Search for the Good Life; Clancy, M., Ed.; Routlegde: London, UK, 2017; $248 \mathrm{p}$.

45. Wilson, T.; Ypeij, A. Tourism, gender and ethnicity. Lat. Am. Perspect. 2012, 39, 5-16. [CrossRef]

46. Chen, H.; Rahman, I. Cultural Tourism: An analysis of engagement, cultural contact, memorable tourism experience and destination loyalty. Tour. Manag. Perspect. 2018, 26, 153-163. [CrossRef]

47. Mowford, M.; Munt, I. Tourism and Sustainability: Development, Globalisation and New Tourism in the Third World, 3rd ed.; Routledge: London, UK, 2008; p. 448. ISBN 978-1-138-01326-1.

48. Fox, N.; Hunn, A.; Mathers, N. Sampling and Sample Size Calculation. The NIHR RDS for the East Midlands, Yorkshire \& the Humber. 2007. Available online: https://www.researchgate.net/profile/Mansour_Abdullah_ Alshehri/post/How_to_determine_population_and_sample_size_for_a_survey_research/attachment/ 5aa18dfc4cde266d58902255/AS\%3A601990316974080\%401520537084240/download/Sampling+Sample+ Size+Calculation.pdf (accessed on 12 July 2019).

49. Super Office. Seven Ways to Create a Great Customer Experience Strategy. 2017. Available online: https://www.superoffice.com/blog/customer-experience-strategy/ (accessed on 25 March 2018).

50. Oriade, A.; Evan, M. Sustainable and Alternative Tourism. In Research Themes for Tourism; Robinson, P., Heitman, S., Dieke, C., Eds.; CABI: Wallingford, UK, 2011; pp. 69-87.

51. Hernández-Mogollón, J.M.; Duarte, P.A.; Folgado-Fernández, J.A. The contribution of cultural events to the formation of the cognitive and affective images of a tourist destination. J. Destin. Mark. Manag. 2018, 8, 170-178. [CrossRef]

52. Região Autónoma da Madeira. Estratégia para o turismo da madeira 2017-2021, Região Autónoma da Madeira. 2016. Available online: https://estrategia.turismodeportugal.pt/sites/default/files/Doc_Estrategico_ Turismo_RAM_0.pdf (accessed on 10 April 2018).

53. Slee, B.; Farr, H.; Snowdon, P. The economic impact of alternative types of rural tourism. J. Agric. Econ. 1997, 48, 179-192. [CrossRef]

54. Sims, R. Food, place and authenticity: Local food and the sustainable tourism experience. J. Sustain. Tour. 2009, 17, 321-333. [CrossRef]

55. Sanagustín, M.V.; Moseñe, J.A.; Patiño, M.G. Rural tourism: A sustainable alternative. Appl. Energy 2011, 88, 551-557. [CrossRef]

56. Fernández-Mogollón, J.M.; Di-Clemente, E.; Campón-Cerro, A.M.; Folgado-Fernández, J.A. The experiential value of slow tourism: A Spanish perspective. In Slow Tourism, Food and Cities; Michael, C., Ed.; Routledge: London, UK, 2018; pp. 181-197.

57. 50Kazeminia, A.; Hultman, M.; Mostaghel, R. Why pay more for sustainable services? The case of ecotourism. J. Bus. Res. 2016, 69, 4992-4997. [CrossRef] 
58. De Salvo, P.; Calzatti, V. Slow Tourism: A theoretical framework. In Slow Tourism, Food and Cities. Pace and the Search for the Good Life; Clancy, M., Ed.; Routledge: London, UK, 2018.

59. 52Pulido-Fernández, J.I.; López-Sánchez, Y. Are tourists really willing to pay more for sustainable destinations? Sustainability 2016, 8, 1240. [CrossRef]

60. DREM. Indicadores Estatísticos, Direção Regional de Estatística da Madeira. Available online: https: //estatistica.madeira.gov.pt/ (accessed on 12 June 2018).

61. SRETC. Estratégia para o Turismo da Madeira, 2017-2021, Secretaria Regional da Economia, Turismo e Cultura. 2017. Available online: http://www.visitmadeira.pt/Admin/Public/Download.aspx?file=Files $\% 2 F F i l e s \%$ 2FVisitMadeira\%2FEstudos\%2Fj-DOCUMENTO-ESTRATEGICO-2017-21.pdf (accessed on 2 April 2018).

62. Jesus, E. Madeira: Developing a new tourism paradigm. Worldw. Hosp. Tour. Themes 2016, 8, 711-715. [CrossRef]

63. Maroco, J.; Bispo, R. Estatística Aplicada às Ciências Sociais e Humanas; Climepsi Editores: Lisbon, Portugal, 2003; 358p, ISBN 927-769-065-0.

64. RIS3-RAM. Madeira 2020 Estratégia Regional de Especialização Inteligente RIS3, Agência Regional para o Desenvolvimento da Investigação, Tecnologia e Inovação (ARDITI). 2014. Available online: https://www. portugal2020.pt/Portal2020/Media/Default/Docs/EstrategiasEInteligente/EREI\%20Madeira.pdf (accessed on 10 April 2018).

65. DETRAM. Documento Estratégico para o Turismo na RAM (2015-2020), ACIF, KPMG. Available online: http://estrategia.turismodeportugal.pt/sites/default/files/Doc_Estrategico_Turismo_RAM_0.pdf (accessed on 26 May 2016).

66. Buckley, R. Sustainable tourism: Research and reality. Ann. Tour. Res. 2012, 39, 528-546. [CrossRef]

67. Broggi, M. Sanfter tourismus: Schlagwort oder Chance fur den Alpenraum. In Le Tourismedoux, Slogan Oubienfait Pour L'espacealpin? Broggi, M.F., Übers, Chappuis, J., Eds.; Commission Internationale pour las Protection des Regions Alpines: Chur, Switzerland, 1985.

68. Brum da Silveira, A.; Madeira, J.; Ramalho, R.; Fonseca, P.; Prada, S. Notícia explicativa da Carta Geológica da Madeira, na escala 1:50.000, Folhas (A) e (B); Secretaria Regional do Ambiente e Recursos Naturais, Região Autónoma da Madeira; Universidade da Madeira: Funchal, Portugal, 2010; 47p, ISBN 978-972-98405-2-4.

69. Eurostat. Tourism Statistics; 2016 ed.; European Union Publications: Brussels, Belgium, 2016. [CrossRef]

70. FundacióGadeso. El Turisme a les Illes Baleares Anuari 2016; FundacióGadeso: Palma, Spain, 2017; 259p.

71. Gran Canaria Tourist office. Situation of the Tourism Sector-Annual Report; Cabildo de Gran Canaria: Gran Canaria, Spain, 2015.

72. Hall, C. Introduction: Culinary tourism and regional development: From slow food to slow tourism? Tour. Rev. Int. 2006, 9, 303-305. [CrossRef]

73. Heitman, S. Authenticity in Tourism. In Research Themes for Tourism; Robinson, P., Heitman, S., Dieke, P., Eds.; CABI International: Wallingford, UK, 2011; pp. 45-59.

74. Insee. Bilan annuel du tourisme-2016. Insee Dossier Corse. Available online: http://www.corsica-pro.com/fr/ observatoire/etudes/chiffres-cles (accessed on 22 June 2018).

75. Instituto Nacional de Estatística. Estatísticas do Turismo 2017. ISBN 978-989-25-0447-6. Available online: https://www.google.com.hk/url?sa=t\&rct=j\&q=\&esrc=s\&source=web\&cd=1\& ved=2ahUKEwiyyNmy2YHkAhXFBKYKHY6xAe4QFjAAegQIABAC\&url=https\%3A\%2F\%2Fwww.ine. pt\%2Fngt_server\%2Fattachfileu.jsp\%3Flook_parentBoui\%3D337818965\%26att_display\%3Dn\%26att_ download\%3Dy\&usg=AOvVaw14uqh3XOjg-bOEveAQntU_ (accessed on 22 April 2018).

76. Jesus, E. Madeira tourism strategy: How to re-qualify a destination. Worldw. Hosp. Tour. Themes 2017, 9, 659-662. [CrossRef]

77. Krippendorf, J. The Holidaymakers: Understanding the Impact of Leisure Travel; Butterworth Heinemann: London, UK, 1987; 160p, ISBN 978-075-06-4348-1.

78. Markwell, K.; Fullagar, S.; Wilson, E. Reflecting upon slow travel and tourism experiences. In Slow Tourism: Experiences and Mobilities; Fullagar, S., Markwell, K., Wilson, E., Eds.; Channel View: Bristol, UK, 2012; pp. 99-112.

79. Smith, S. Experiencia de marca. In En Clave de Marcas; Brujó, G., Ed.; Lid editorial: Madrid, Spain, 2010; 344p.

80. Tosun, C. Challenges of sustainable tourism development in the developing world: The case of Turkey. Tour. Manag. 2001, 22, 289-303. [CrossRef] 
81. WTTC. Travel E Tourism Economic Impact, Cyprus; World Travel \& Tourism Council: London, UK, 2017.

82. Zlatareva, N. Alternative and Mass Tourism Combination Analysis in South Europe. Young Scientist USA; Lulu Press: Auburn, WA, USA, 2015; Volume 2, p. 40. Available online: www.youngscientistusa.com/archive/2/222/ (accessed on 25 March 2018). 